Dominika DzIWISZ

\title{
Bezpieczeństwo danych osobowych w erze Big Data - ograniczenia i dylematy stosowania „prawa do bycia zapomnianym”
}

Abstract: In response to the challenges of personal data security, catalyzed by the development of modern information technologies, the European Parliament and the Council of the European Union adopted on 27 April 2016 its Regulation on the protection of natural persons with regard to the processing of personal data and on the free movement of such data (GDPR). One of the most frequently discussed provisions of the GDPR is the so-called right to be forgotten. It aims primarily to give control back to citizens and residents over their personal data. At least in theory it gives individuals a right to have their personal data erased and to prevent processing of these data in specific circumstances. The aim of this article is to answer the question to what extent and under what conditions the right to be forgotten can be effectively implemented in the $21^{\text {st }}$ century.

Kerwords: Big Data, personal data security, GDPR, right to be forgotten

\section{Wprowadzenie}

Od początku dziejów człowiek starał się zapamiętywać jak najwięcej, aby przekazywać wiedzę przyszłym pokoleniom oraz utrwalać wspomnienia. W tym celu tworzył 
malowidła ścienne w jaskiniach, zapisywał zwoje papirusu, potem papieru, robił zdjęcia, nagrywał taśmy i plyty muzyczne, a w końcu budowal komputery. Wraz z postępem technicznym i technologicznym sposoby zapisywania informacji stawaly się coraz bardziej niezawodne. Jednak dopiero wprowadzenie do powszechnego użytku komputerów osobistych i Internetu na początku lat 80. XX stulecia zapoczątkowało rewolucyjne zmiany w przechowywaniu danych. Od tego czasu kilobajty danych byly przechowywane na taśmach i dyskietkach komputerowych, a następnie megabajty danych były zapisywane na twardych dyskach komputerów albo dyskach pogrupowanych w macierzach dyskowych. Rozwój technologii sieciowych umożliwił stworzenie tańszej alternatywy dla nadmiernej rozbudowy pojedynczych urządzeń. Obecnie coraz częściej dane są przechowywane i przetwarzane w chmurze obliczeniowej (ang. cloud computing).

Jeszcze w 2000 r. tylko jedna czwarta informacji była zgromadzona $w$ formie cyfrowej ${ }^{1}$. Przełomowy dla zapamiętywania był 2002 r., kiedy liczba danych cyfrowych przewyższyła liczbę danych analogowych. Dlatego symbolicznie można przyjąć tę datę za koniec ery analogowej, a początek cyfrowej². Współcześnie w ciągu godziny ludzkość generuje około $80 \mathrm{~PB}$ (petabajtów ${ }^{3}$ ) danych ${ }^{4}$. Oznacza to, że gdyby wszystkie zgromadzone informacje zapisać na plytach CD i ustawić jedna na drugiej, powstaloby pięć kolumn lączących Ziemię z Księżycem5. Obecnie prawie wszystkie tworzone treści mają swoje odwzorowanie w ciągach zer i jedynek. Jest tak m.in. dlatego, że cena przechowywania gigabajta pamięci z roku na rok spada o 30-40\% ${ }^{6}$. Rośnie liczba serwisów internetowych, w których przechowywanie informacji nic nie kosztuje. Przykładowo w serwisie internetowym Flickr, który umożliwia gromadzenie i udostępnianie zdjęć cyfrowych online można nieodplatnie przechowywać aż 1 terabajt

1 M. Hilbert, P. López, How to Measure the World's Technological Capacity to Communicate, Store, and Compute Information Part I: Results and Scope, International Journal of Communication" 2012, nr 6. 2 Ibidem.

3 Petabajt (PB) to stosowana w informatyce jednostka pojemności pamięci równa biliardowi (1 000 $000000000000=1015$ ) bajtów. W 2012 r. popularny serwis spolecznościowy Facebook zgromadzil 180 PB danych, a co 24 godziny przybywalo okolo 0,5 PB. Za: S. S h a r wood, Facebook Warehousing 180 PETABYTES of Data a Year, ${ }_{n}$ The Register", 9 XI 2012, www.theregister.co.uk/2012/11/09/ facebook_open_sources_corona/, 15 IX 2016.

4 J. Enriquez, Reflections in a Digital Mirror, [w:] The Human Face of Big Data, red. R. S mol an, J. Erwitt, Sausalito, CA 2012, s. 18, za: A. Czubik [et al.], Nowe wyzwania dla ochrony praw czlowieka, Kraków 2017, s. 97.

5 V. Mayer-Schönberger, K. Cukier, Big Data. Rewolucja, która zmieni nasze myślenie, praç $i \dot{z} y c i e$, Warszawa 2014, s. 24.

6 P. Górecki, Wróżba z komputera, „Newsweek", 4 XII 2010, www.newsweek.pl/nauka/wrozbaz-komputera,68916,1,1.html, 21 IX 2016. 
(TB) zdjęć $c^{7}$. To mniej więcej tyle co $1 \mathrm{mln}$ odbitek fotograficznych albo 25 tys. rolek filmu fotograficznego. Nowe możliwości taniego przechowywania danych sprawily, że wybór opcji nzapisz" stał się najbardziej racjonalny, ponieważ to nic nie kosztuje, a być może kiedyś informacja się przyda. $Z$ tego powodu współczesny czlowiek nie selekcjonuje danych, ale zapisuje wszystko na wszelki wypadek. To doprowadziło do odwrócenia dotychczasowej sytuacji kulturowej, w której zapominanie było normą, a stało się wyjątkiem ${ }^{8}$. Można zatem powiedzieć, że zapamiętywanie stało się „opcją domyślną" naszych czasów”. Celnie to ujął Viktor Mayer-Schönberger, twierdząc, że nawet decydowanie, czy zapamiętać czy zapomnieć, nie jest już ekonomicznie rozsądne ${ }^{10}$. Tańsze i szybsze komputery przyjmują i przetwarzają coraz większe zasoby danych na nasz temat. Łącząc $w$ całość cyfrowe ślady, jakie po sobie pozostawiamy, takie jak logi (ang. logs) z serwerów i serwisów internetowych, popularne lajki, filmy i zdjęcia, zapisy transakcji sklepowych czy koordynaty GPS, można otrzymać szczególową wiedzę o naszych zachowaniach, przyzwyczajeniach i preferencjach. Michał Kosiński, psycholog z Uniwersytetu Stanforda, twierdzi nawet, że nwystarczy pokazać dziesięć lajków danego człowieka, aby [komputer - przyp. aut.] był dokładniejszy niż jego znajomi z pracy. Sto lajków, aby był dokładniejszy niż jego rodzina. A przy dwustu czterdziestu lajkach komputer będzie dokładniejszy od jego partnera życiowego. Taką ilość lajków niektórzy produkują w ciągu tygodnia" ${ }^{n 11}$.

W odpowiedzi na wyzwania bezpieczeństwa danych osobowych katalizowanych rozwojem nowoczesnych technologii informatycznych Parlament Europejski i Rada Unii Europejskiej przyjęły 24 października 1995 r. dyrektywę nr 95/46/WE w sprawie ochrony osób fizycznych w zakresie przetwarzania danych osobowych i swobodnego przeplywu tych danych. Po ponad 20 latach obowiązywania dyrektywy jej przepisy przestały odpowiadać nowym zagrożeniom związanym z rozwojem Internetu. Warto wspomnieć, że kiedy przyjmowano dyrektywę nr 95/46/WE, założyciel najpopular-

7 Nie bez znaczenia jest też cena samych komputerów, które obecnie są tańsze o okolo $99,9 \%$ niż w r. 1982. Za: A. I to, Six Things Technology Has Made Insanely Cheap. Bebold the power of American progress, „Bloomberg”, 5 II 2015, https://www.bloomberg.com/news/articles/2015-02-05/sixthings-technology-has-made-insanely-cheap?hootPostID =f0584f28d45d0ddc91cf8868351d2 ba6, 11 X 2017.

- M. Halawa, Nowe media i archiwizacja życia codziennego, „Kultura Wspólczesna" 2011, nr 11, s. 21-47.

9 Ibidem.

10 V. Mayer-Schönberger, Delete: the Virtue of Forgetting in the Digital Age, Princeton-Oxford 2009, s. 68.

11 M.Szym an iak, Polak odkryt politycznq bombe atomowq. To koniec demokracji jakq znamy?, TVN24, www.tvn24.pl/magazyn-tvn24/polak-odkryl-polityczna-bombe-atomowa-to-koniec-demokracjijaka-znamy,79,1628, 24 I 2017. 
niejszego serwisu spolecznościowego Facebook Mark Zuckerberg miał 13 lat, Google dopiero co został założony, a cloud computing raczkował ${ }^{12}$. Nowe rozporządzenie Parlamentu Europejskiego i Rady Unii Europejskiej 2016/679 z dnia 27 kwietnia 2016 r. w sprawie ochrony osób fizycznych w związku z przetwarzaniem danych osobowych i w sprawie swobodnego przeplywu takich danych (dalej nazywane RODO) ${ }^{13}$ ma stanowić odpowiedź na potrzeby zdigitalizowanego świata. We wszystkich 28 państwach czlonkowskich Unii Europejskiej nowe przepisy zajęły miejsce dotychczas obowiązujących odpowiedników polskiej ustawy o ochronie danych osobowych i weszły w życie 25 maja 2018 r.

Jednym $z$ najgoręcej dyskutowanych zapisów RODO jest tzw. prawo do bycia zapomnianym (ang. right to be forgotten). Najogólniej mówiąc, to prawo ma się sprowadzać do usunięcia wszelkich informacji z systemu administratora na temat osoby, która chce być „zapomniana". Wiąże się z tym szereg kontrowersji. Pierwsza, prawdopodobnie najczęściej dyskutowana, dotyczy tego, że dzięki prawu do bycia zapomnianym różne osoby, m.in. wcześniej karane, będą mogły uciec od przeszlości. Innymi słowy, byłby to legalny mechanizm usuwania niewygodnych informacji, swoista ncyfrowa amne$z{ }^{n}$. W konsekwencji prawo do bycia zapomnianym może też kolidować $\mathrm{z}$ wolnością wypowiedzi ${ }^{14}$, ponieważ oznacza ono nie tylko możliwość wymazania niesprawiedliwych i nieprawdziwych informacji na nasz temat, ale także takich, które pokazują nas w niekorzystnym świetle, ale są prawdziwe. Decyzja o usunięciu bądź nieusunięciu

12 Por. Kowalczuk-Pakula: Skończyty sif żarty z ochronq danych osobowych $w U E,{ }_{n}$ Gazeta Prawna", 9 VI 2016, http://prawo.gazetaprawna.p//artykuly/950521,kowalczuk-pakula-skonczyly-sie-zartyz-ochrona-danych-osobowych-w-ue.html, 15 X 2017.

13 Rozporzadzenie Parlamentu Europejskiego i Rady (UE) 2016/679 z dnia 27 kwietnia 2016 r. wsprawie ochrony osób fizycznych w zwiqzku $z$ przetwarzaniem danych osobowych $i$ w sprawie swobodnego przeplywu takich danych oraz uchylenia dyrektywy 95/46/WE (ogolne rozporzadzenie o ocbronie danych), „Dziennik Urzędowy Unii Europejskiej" 2016, nr L 119, https://eur-lex.europa.eu/legal-content PL/TXT/?qid=1539941625494\&uri=CELEX:32016R0679, 11 X 2017.

14 Obawy te nie pokrywają się z opiniami obywateli UE. Wyniki badania Eurobarometru z 2011 r. wskazują, że aż $75 \%$ z nich chcialoby korzystać z prawa do bycia zapomnianym, czyli usuwać w dowolnym momencie informacje online na swój temat, a $90 \%$ badanych jest zgodnych, że w całej Europie powinny obowiązywać te same uregulowania w tym zakresie. Natomiast wydaje się, że w USA, inaczej niż w Europie, prawo do prywatności jest wartością nadrzędną i chronioną bardziej niż w Europie. Za: 75 proc. Europejczyków chcialoby zapomnienia w sieci, Fundacja Panoptykon, 21 VI 2011, https://panoptykon.org/wiadomosc/75-proc-europejczykow-chcialoby-zapomnienia-w-sieci, 21 I 2018; Attitudes on Data Protection and Electronic Identity in the European Union, June 2011, European Commission, http://ec.europa.eu/commfrontoffice/publicopinion/index.cfm/Survey/ getSurveyDetail/yearFrom/1974/yearTo/2011/surveyKy/864, 19 V 2018; J. Hendel, In Europe, a Right to Be Forgotten Trumps the Memory of the Internet, "The Atlantic", 3 II 2011, https://www. theatlantic.com/technology/archive/2011/02/in-europe-a-right-to-be-forgotten-trumps-thememory-of-the-internet/70643/, 16 X 2017. 
informacji będzie należała do administratora danych. Innymi słowy, firmy takie jak Facebook czy Google z neutralnych platform wymiany informacji zmienią się w globalnych cenzorów informacji. Zdaniem niektórych stoi to $\mathbf{w}$ sprzeczności z zasadą wolności słowa, bo nie powinno się ograniczać publikowania zawstydzających, ale wiarygodnych informacji ${ }^{15}$. Drugi często wysuwany argument krytyczny sprowadza się do aspektów technicznych i technologicznych usuwania informacji, a mianowicie tego, w jakiej mierze w praktyce da się skutecznie usunąć pewne informacje $z$ Internetu.

Wymienione powyżej kwestie, techniczna $i_{\text {n }}$ cyfrowej amnezji”, nie wyczerpują listy obaw związanych ze stosowaniem prawa do bycia zapomnianym, ale w subiektywnej ocenie autorki są najbardziej podstawowe i interesujące. Dlatego wyznaczonym celem badawczym jest uzyskanie odpowiedzi na pytania: w jakim stopniu, czy w ogóle, oraz na jakich warunkach prawo do bycia zapomnianym może być skutecznie realizowane w XXI w.

\section{Prawo do bycia zapomnianym na gruncie prawa europejskiego}

Wymazywanie pamięci o ludziach nie jest zjawiskiem nowym. Instrument temu slużący istniał już w starożytnym Egipcie. W myśl egipskich wierzeń zniszczenie imienia było okrutną karą, bo oznaczało tyle co unicestwienie czlowieka. Zgodnie z zapisami Ksiegi umarlych, staroegipskim zbiorem wskazówek mających ułatwić zmarlemu przejście do raju, każdy po śmierci musial skonfrontować się ze strażnikami bram nieba. Aby przekonać albo pokonać strażnika-demona konieczna była znajomość jego imienia ${ }^{16}$. Dlatego znaczenie imienia dla Egipcjan miało wymiar nie tylko magiczny, ale jednocześnie stanowilo instrument kontroli. Także we współczesnym Egipcie po odsunięciu od władzy Hosniego Mubaraka jego imię i nazwisko, a także ślady pamięci jego żony musiały zostać usunięte $z$ nazw ulic, bibliotek $\mathrm{i}$ innych instytucji publicznych ${ }^{17}$. Historycznie procedura "potępienia pamięci" (łac. damnatio memoriae) funkcjonowała również, z różnych powodów, w starożytnych Grecji i Rzymie, a wiele wieków później m.in. w Związku Radzieckim, na Kubie i w Chińskiej Republice Ludowej. Różnica w znaczeniu różnych instrumentów zapomnienia polega na tym, że nie tylko w przeszłości, ale i wspólcześnie bywa to formą kary. Obecnie wymazywanie pamięci

is J. Rosen, The Right to Be Forgotten, ,The Atlantic", lipiec/sierpien 2012, https://www.theatlantic. com/magazine/archive/2012/07/the-right-to-be-forgotten/309044/, 16 X 2017.

16 M. B a rwik, Ksiegga wychodzenia za dnia. Tajemnice egipskiej Ksiegi Umartych, Warszawa 2009.

17 S. E. Bond, Erasing the Face of History, ${ }_{n}$ The New York Times", 14 V 2011, http://www.nytimes. com/2011/05/15/opinion/15bond.html?_r=1, 10 X 2017. 
zyskało zupełnie nowe znaczenie. W wymiarze wirtualnym jest to prawo i przywilej, który pozwala zatrzeć ślady naszej, często niechlubnej przeszłości.

Inspiracją do rozpoczęcia prac nad prawem obywateli UE do „bycia zapomnianym” stała się konkluzja, że w systemach prawnych nawet sprawcy najcięższych przestępstw przysługuje zatarcie skazania po upływie określonego czasu. W Internecie to prawo nie ma swojego odpowiednika, bo żadna informacja, która trafia do sieci, nigdy nie znika $^{18}$. Nierozważne zamieszczanie informacji na swój temat, ale także publikowanie informacji o nas przez osoby trzecie, może utrudniać życie w przyszłości. Każda informacja, która trafia do sieci, tworzy nelektroniczny tatuaż ${ }^{n}$ naszych zachowań, którego nie da się usunąć. Pierwszy raz na ten temat wypowiedział się Trybunał Sprawiedliwości UE na kanwie sprawy Google Spain (C-131/12) ${ }^{19}$. Wyrok Trybunału zapadl w sprawie skargi, którą obywatel Hiszpanii złożył na działania, a właściwie na brak działań właściciela najpopularniejszej wyszukiwarki świata - Google. W 2010 r. Mario Costeja González wniósł do hiszpańskiej agencji ochrony danych (Agencia Española de Protección de Datos - AEPD, odpowiednika polskiego Generalnego Inspektora Ochrony Danych Osobowych - GIODO) skargę skierowaną przeciwko wydawcy wysokonakładowego dziennika oraz przeciwko spółkom Google Spain i Google Incorporated. Twierdzil, że przy wprowadzaniu jego imienia i nazwiska do wyszukiwarki Google Search wysoko na liście wyników pojawial się link do dwóch stron gazety „La Vanguardia". W dzienniku można było odszukać ogłoszenie o licytacji nieruchomości, która miała związek z niespłaconymi przez Gonzáleza należnościami na rzecz zakładu ubezpieczeń spolecznych. González chcial, żeby AEPD nakazała wydawcy usunięcie lub zmianę treści tych stron. Jak uzasadniał, sprawa zajęcia nieruchomości została rozwiązana już wiele lat temu i obecnie wzmianka o niej nie ma żadnego znaczenia. Można się domyślać, że jednak informacja o zadłużeniu była niewygodnym faktem, który utrudnial życie prywatne i zawodowe powoda. Zgodnie z decyzją AEPD skarga została oddalona w zakresie dotyczącym dziennika "La Vanguardia”, gdyż wydawca ten opublikował rozpatrywane informacje zgodnie z prawem. Skarga Gonzáleza została jednak uwzględniona w zakresie dotyczącym Google Spain i Google Inc., a spółki zostały zobowiązane do usunięcia danych $\mathrm{z}$ indeksów oraz zablokowania dostępu do nich w przyszłości. Od tej decyzji Google Spain i Google Inc. odwołały się do hiszpańskiego sądu, ale ten, ze względu na liczne wątpliwości prawne, sporu nie rozstrzygnął

18 M. Krzysztofek, "Prawo do bycia zapomnianym" $i$ inne aspekty prywatnosici w epoce Internetu w prawie UEI, „Europejski Przegląd Sądowy" 2012, nr 8, s. 31.

19 Judgment of the Court (Grand Chamber), 13 May 2014, Google Spain SL and Google Inc. v Agencia Española de Protección de Datos (AEPD) and Mario Costeja González, http://eur-lex.europa.eu/legalcontent/EN/ALL/?uri=CELEX:62012CJ0131, 10 X 2017. 
i zwrócił się do Trybunału Sprawiedliwości UE o rozpatrzenie sprawy. Wyrokiem $z$ dnia 13 maja 2014 r. Trybunał utrzymał, że noperator wyszukiwarki internetowej jest odpowiedzialny za dokonywanie przezeń przetwarzania danych osobowych, które pojawiają się na stronach internetowych publikowanych przez osoby trzecie ${ }^{n 20}$. Wyrok Trybunału otworzył obywatelom UE drogę do latwiejszego usuwania informacji $z$ Internetu na ich temat.

27 kwietnia 2016 r. przyjęto rozporządzenie Parlamentu Europejskiego i Rady Unii Europejskiej w sprawie ochrony osób fizycznych w związku z przetwarzaniem danych osobowych i w sprawie swobodnego przeplywu takich danych. Rozporządzenie jest stosowane od dnia 25 maja 2018 r. Glównym celem RODO jest doprowadzenie do pełnej harmonizacji prawa w ramach UE i swobodnego przeplywu danych osobowych. Zgodnie z RODO prawo do bycia zapomnianym w praktyce sprowadza się do tego, że jeśli po wpisaniu w wyszukiwarkę swojego imienia i nazwiska wyświetli się link do strony $\mathrm{z}$ informacją o nas, to można zwrócić się do administratora z prośbą o usunięcie tego linku, a także usunięcie kopii zapasowych informacji. Prawo to nie ma jednak charakteru bezwzględnego, a zgodnie $z$ art. 17 ust. 1 RODO może być realizowane tylko wtedy, gdy zajdzie jedna $\mathrm{z}$ następujących okoliczności:

1. dane nie są już dłużej niezbędne do realizacji celu, w jakim zostały zebrane lub są przetwarzane;

2. podmiot danych wycofal zgodę na przetwarzanie jego danych osobowych oraz nie istnieją podstawy prawne, aby mimo tego kontynuować przetwarzanie;

3. podmiot danych sprzeciwia się przetwarzaniu oraz nie występują nadrzędne prawnie uzasadnione podstawy przetwarzania;

4. podmiot danych sprzeciwia się przetwarzaniu jego danych osobowych na potrzeby i w zakresie marketingu bezpośredniego (w tym profilowania);

5. przetwarzanie $w$ inny sposób nie jest lub nie bylo zgodne $z$ RODO lub innymi przepisami prawa;

6. dane osobowe zostały zebrane w nawiązaniu do oferowania bezpośrednio osobom poniżej 16 lat usług spoleczeństwa informatycznego (np. e-handel, portale społecznościowe) ${ }^{21}$.

20 Ibidem.

21 Rozporządzenie zezwala państwom członkowskim na ustalenie niższej granicy wieku w tym zakresie. Musi ona wynosić co najmniej 13 lat. Zgoda na przetwarzanie danych dziecka, które nie ukończyło 16 lat, musi być wyrażona albo zaaprobowana przez osobę sprawującą władzę rodzicielską lub opiekę nad dzieckiem i tylko w zakresie wyrażonej zgody. Za: http://www.giodo.gov.pl/pl/p/ informacje-ogolne, 16 X 2017. 
Chociaż od decyzji administratora danych przysługuje prawo odwolania się do krajowego inspektora ochrony danych osobowych (w Polsce - Generalny Inspektor Ochrony Danych Osobowych), to jednak ogólne podejście do regulacji danych osobowych zmieniło się w zasadniczy sposób ${ }^{22}$. Odchodzi się bowiem od modelu opartego na bardzo aktywnej roli GIODO w kierunku modelu, w którym administratorzy danych będą musieli podejmować większość decyzji samodzielnie. Rozporządzenie jest także bardziej wymagające od dotychczas obowiązujących przepisów, ponieważ nie wskazuje konkretnych rozwiązań, lecz nakłada na przedsiębiorcę odpowiedzialność za dobranie zabezpieczeń adekwatnych do poziomu ryzyka ${ }^{23}$. To będzie wymagało zmian organizacyjnych, w tym przede wszystkim zatrudnienia zespołów specjalizujących się w ochronie danych. Warto tutaj zwrócić uwagę na to, że skoro odpowiedzialność za bezpieczeństwo danych została przeniesiona na przedsiębiorstwa prywatne, to kontrolerem realizacji prawa do prywatności, pomimo braku mandatu publicznego, zostali giganci sektora IT, a procedury oceny wniosków o usunięcie informacji mogą być inne w każdej firmie.

\section{Prawo do bycia zapomnianym - ograniczenia i dylematy}

\section{stosowania}

Mimo że przepisy RODO weszły w życie dopiero w maju 2018 r., to już w 2014 r. Google umożliwił składanie wniosków o usunięcie linków poprzez specjalny formularz internetowy. Do podejmowania decyzji o odrzuceniu bądź przyjęciu wniosku powolano komitet doradczy złożony z ekspertów różnych dziedzin - informatyków, prawników, a nawet filozofów Internetu ${ }^{24}$. Wbrew częstym opiniom, że z prawa do bycia zapomnianym będą korzystać glównie politycy i osoby publiczne albo przestęp-

22 Wypowiedź Pawła Litwińskiego dla: S. Wikariak, Google, Facebook czy Apple będq musialy przestrzegac regut. Reforma ocbrony danych osobowych stata sie faktem, ${ }_{n}$ Gazeta Prawna", 14 IV 2016, http:// prawo.gazetaprawna.pl/artykuly/936232,reforma-ochrony-danych-osobowych.html, 16 X 2017.

${ }_{23} \mathrm{~K}$. Chwastowski, Rozporzadzenie $P E$ i Rady w sprawie ochrony osob fizycznych w zwiqzku z przetwarzeniem danych osobowych, ,Rzeczpospolita", 2 VI 2017, http://www.rp.pl/Daneosobowe/306029979-Rozporzadzenie-PE-i-Rady-w-sprawie-ochrony-osob-fizycznych-w-zwiazku2-przetwarzaniem-danych-osobowych.html, 16 X 2017.

${ }_{24}$ D. Sulliva n, How Google's New ${ }_{n}$ Right To Be Forgotten ${ }^{n}$ Form Works: An Explainer, ${ }_{n}$ Search Engine Land", $30 \mathrm{~V}$ 2014, https://searchengineland.com/google-right-to-be-forgotten-form-192837, 16 X 2017); J. V incent, Google Begins Implementation Of 'Right To Be Forgotten' Ruling With Online Takedown Form, "The Independent ${ }^{n}, 30 \mathrm{~V}$ 2014, http://www.independent.co.uk/life-style/gadgetsand-tech/google-begins-implementation-of-right-to-be-forgotten-ruling-with-online-takedownform-9459209.html, 16 X 2017. 
cy, statystyki raportu w sprawie przejrzystości Google'a temu przeczą ${ }^{25}$. Ponad 95\% wniosków o usunięcie linków $z$ indeksów pochodzi od osób prywatnych i dotyczy usunięcia informacji o ich życiu prywatnym. Mniej niż 5\% wniosków pochodzi od osób publicznych, polityków, ale także od przestępców ${ }^{26}$. W okresie od 28 maja 2014 r. do 10 października 2017 r. do Google’a wplynęło prawie dwa miliony wniosków o usunięcie informacji, z czego większość $(56,8 \%)$ została rozpatrzona negatywnie. Wśród czynników, jakie miały wpływ na negatywne rozpatrzenie wniosku, były: istnienie alternatywnych rozwiązań, względy techniczne albo istniejący duplikat URL. Nie usuwano także linków do stron $\mathrm{z}$ informacjami będącymi w interesie publicznym, czyli np. takich, które odnoszą się do życia zawodowego osoby publicznej, jej przeszłości przestępczej, zajmowanego stanowiska politycznego, a także treści dokumentów rządowych albo treści autoryzowanych przez wnioskującego. Przykładowo nie usunięto linków do artykułów prasowych na temat badania naukowego zawierających zdjęcie jednego $z$ uczestników badania, który później zmienił pleć oraz imię. W uzasadnieniu podano, że artykuły te są nadal istotne dla oceny życia zawodowego naukowca, który zgłosił żądanie ${ }^{27}$. Nie usunięto także stron $\mathrm{z}$ informacją o parze Austriaków oskarżonej o przestępstwa biznesowe, a taki̇e o francuskim księdzu skazanym za posiadanie materiałów pornografii dziecięceje ${ }^{28}$. Pozytywnie natomiast rozpatrzono wniosek kobiety, która chciała usunąć artykuł sprzed kilku lat o morderstwie jej męża, w którym pojawiało się jej imię i nazwisko, a także Belgijki, która nie chciała być kojarzona z konkursem, który wygrała w młodości. Zgodnie ze statystykami Google’a najwięcej usuwanych linków prowadzi do domeny internetowej www.facebook.com (portal spolecznościowy), annuaire.118712.fr (francuska baza teleadresowa), profileengine.com (strona, na której udostępniane są profile skopiowane z Facebooka) ${ }^{29}$ oraz twitter.com (serwis spolecznościowy $\mathrm{z}$ usługą mikroblogowania) ${ }^{30}$.

Statystyki $z$ raportu $w$ pewnym stopniu niwelują obawy związane $z$ tym, że prawo do bycia zapomnianym będzie służyło głównie jako mechanizm usuwania informacji

25 Google Transparency Report: Search removals under European privacy law, https://transparencyreport. google.com/eu-privacy/overview, 17 X 2017.

26 Ibidem.

27 Ibidem.

28 Ibidem.

29 Profile Engine to strona internetowa, o której mało kto slyszal, ale ta wie o nas bardzo dużo, bo udostępnia publicznie prawdziwe profile ludzi z Facebooka, ze wszystkimi informacjami, które na nim udostępnili. Ta firma skopiowała $420 \mathrm{mln}$ profili z Facebooka i udostępnia je wszystkim publicznie pod adresem profileengine.com. Warto wspomnieć, że profile na profileengine.com są nieakrualne, bo pochodzą sprzed paru lat.

30 Przez dlugi czas Google nie indeksowal linków z Twittera. Prawdopodobnie nie chcial przysparzać Twitterowi popularności. 
niewygodnych. Jednak z drugiej strony należy pamiętać, że tak naprawdę nie wiadomo, jakie kryteria i procedury wewnętrzne będą decydować o usunięciu bądź nieusunięciu linku do strony. W każdej firmie mogą być one inne. Ponadto stosowanie prawa do bycia zapomnianym zawsze będzie w części decyzją uznaniową. Pomimo przepisów prawa to czlowiek - pracownik firmy albo zespól pracowników - będzie decydowal o warunkach, na jakich prawo do bycia zapomnianym będzie realizowane. Można powiedzieć, że to nic nowego, bo i tak zawsze wszelkie decyzje administracyjne ostatecznie podejmował czlowiek. W tym wypadku jednak nie decyduje urzędnik administracji, ale pracownik firmy prywatnej. Przyjmując, że najważniejszym celem firmy jest osiągnięcie dobrego wyniku finansowego, istnieje ryzyko, że decyzja taka będzie dyktowana innymi, nie tylko przyjętymi w RODO zasadami. Dlatego będą wydawane także decyzje sporne, a nawet niespójne z przepisami RODO. Taka kontrowersyjna sytuacja zaszla kilka lat temu w związku z artykułem krytykującym bankiera z Wall Street, który zniknął z wyszukiwarki Google w ramach pierwszej próby egzekwowania prawa do bycia zapomnianym w Internecie ${ }^{31}$. Autor usuniętego artykułu oskarżył Google o nabijanie $^{n}$ dziennikarstwa przez ${ }_{n}$ dziwaczne ${ }^{n}$ i ${ }_{n}$ niezdarnen egzekwowanie prawa. Krytycy tej decyzji zareagowali alarmistycznie, podkreślając, że to tylko potwierdza obawy, że sądy będą pomagać bogatym i wpływowym usuwać z Internetu niewygodne, choć prawdziwe informacje na ich temat ${ }^{32}$. Na szczęście od takiej decyzji przysługuje odwołanie do sądu. Jednak sprawy sądowe $z$ reguły toczą się długo, niekiedy latami, co może skutecznie zniechęcać do dochodzenia swoich praw.

Inna obawa związana ze stosowaniem prawa do bycia zapomnianym wiąże się $\mathbf{z}$ aspektami technicznymi usuwania informacji, a mianowicie tego, czy w praktyce da się skutecznie usunąć pewne informacje na zawsze i z każdego miejsca w Internecie. Regulacje unijne ułatwiają usuwanie cyfrowych śladów, które zostawiają po sobie użytkownicy. Jednak nietrudno się domyślić, że nie można usunąć wszystkich informacji na nasz temat. Po pierwsze, jak napisano wcześniej, prawo do bycia zapomnianym nie ma charakteru bezwzględnego i może być realizowane tylko w określonych w art. 17 RODO przypadkach. Po drugie, nierzadko informacje, które zamieszczamy w sieci albo odniesienia do nich, są przez inne osoby lub automatycznie kopiowane na inne serwery i w ten sposób rozprzestrzeniają się w sieci. Efekt jest taki, że choć można usunąć pierwotną informację, to trwale jej usunięcie z sieci jest niezmiernie trudne.

31 A. S pence, Prawo do bycia zapomnianym nowq formq cenzury? Krytyczny artykul dziennikarza

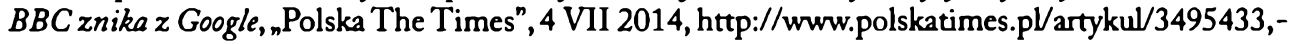
prawo-do-bycia-zapomnianym-nowa-forma-cenzury-krytyczny-artykul-dziennikarza-bbc-znikaz-google,id,t.html, 20 X 2017.

32 Ibidem. 
Informacja, która raz dostała się do Internetu, może być kopiowana nie tylko na inne strony komputerowe, ale też np. na prywatne komputery. Chociaż rozporządzenie nakłada na administratorów danych obowiązek usunięcia informacji ze wszystkich źródeł, to jednak nie tak łatwo zlokalizować dane osobowe, które np. pojawily się w korespondencji elektronicznej między dwoma pracownikami banku ${ }^{33}$. Problematyczne może być również żądanie usunięcia informacji np. $z$ serwerów chińskich ${ }^{34}$. Google albo inna firma utrzymująca bazę danych osobowych nie ma również obowiązku kontaktowania się z użytkownikiem serwisu, aby ten usunął pobrane na swój komputer informacje. Trudno też sobie wyobrazić, że na właścicieli serwisów zostanie nałożona odpowiedzialność za śledzenie, kto i gdzie skopiował informacje o osobie, których usunięcia ta nagle żąda. Przykładem mogą być zdjęcia byłego szefa Formuły 1, które naruszały jego prywatność ${ }^{35}$. Max Mosley wygrał z brytyjskim ${ }_{n}$ News of The World" sprawę o naruszenie dóbr osobistych i dostał odszkodowanie, ale kopie zdjęć zdążyły rozprzestrzenić się w sieci. Wydał kilka milionów funtów na ich śledzenie i usuwanie, ale zdjęcia nadal krążyły w sieci, bo były indeksowane w różnych wyszukiwarkach. Stąd wniosek, że w rzeczywistości użytkownicy Internetu będą zmuszeni wnioskować o usunięcie informacji do wielu serwisów oddzielnie, a prawo do bycia zapomnianym nie będzie w stu procentach egzekwowalne.

Kolejna, często pomijana kwestia sprowadza się do jednej z głównych charakterystyk analizy Big Data, czyli przewartościowania samego znaczenia informacji. Jej wartości nie wyznacza już bowiem podstawowe, obecne wykorzystanie, ale potencjalne wykorzystanie w przyszłości ${ }^{36}$. Nadmiar zgromadzonych informacji tworzy „śmietnik informacyjny", z którego bez specjalistycznych narzędzi nie da się nic wywnioskować. Dopiero przetworzenie przez komputery ogromnych ilości danych może doprowadzić do odkrycia schematów i korelacji, które umożliwią lepsze zrozumienie badanego zjawiska. Dlatego jeszcze kilkanaście lat temu informacje były zbierane w konkretnym celu, a teraz są gromadzone na wszelki wypadek, bo kiedyś mogą się przydać. Oznacza to, że czasami nawet nie mamy świadomości, że informacje na nasz temat, które sami

33 Por. RODO - nowe przepisy o ochronie danych osobowych. Po co powstaty i dlaczego firmy muszq sie pospieszyc?? ${ }_{n}$ Forbes ${ }^{n}, 28$ VIII 2017, https://www.forbes.pl/biznes/rodogdpr-zmiany-w-przepisacho-ochronie-danych-osobowych/e9wq383, 20 X 2017.

34 S. Wikariak, Prawo do bycia zapomnianym nie będzie w 100 proc. egzekwowalne, "Gazeta Prawna”, 25 IV 2016, http://prawo.gazetaprawna.pl/artykuly/938617,bielak-jomaa-prawo-dobycia-zapomnianym.html, 24 X 2017.

35 U. Dauer, L. Fleis her, Former Formula One Chief Max Mosley Settles Legal Dispute With Google, ${ }_{n}$ The Wall Street Journal", 15 V 2015, https://www.wsj.com/articles/former-formula-one-chiefmax-mosley-settles-legal-dispute-with-google-1431702038, 20 X 2017.

36 V. Mayer-Schönberger, K. Cukier, op. cit., s. 73-101. 
zamieszczamy albo ktoś inny zamieszcza w Internecie, mogą zostać wykorzystane w przyszłości. Nieświadomi potencjalnych zagrożeń nie będziemy też wnioskować o ich usunięcie. Zresztą zabraknie uzasadnienia, aby wnioskować o takie działanie.

Do łączenia informacji z różnych źródel, a tym samym tworzenia informacji nowej, służą systemy informatyczne Data Management Platforms. Przykładowo, będąc w posiadaniu informacji, że użytkownik X jest właścicielem nowego modelu iPhone’a i najnowszego samochodu Porsche, a jednocześnie, że X wkrótce wyjedzie do Nowego Jorku, ale nie ma jeszcze zarezerwowanego hotelu, można wnioskować, że X jest osobą zamożną i dlatego warto mu przedstawić reklamę dobrego hotelu. Inny przykład to najnowszy model autonomicznego odkurzacza Roomba, który zostal doposażony w nowe rodzaje czujników ${ }^{37}$. Korzystając z nich, Roomba 980 tworzy mapę pomieszczeń i dzięki temu unika zderzeń z meblami i innymi sprzętami $w$ domu. Firma iRobot może odsprzedać zebrane w ten sposób informacje zainteresowanym przedsiębiorstwom. Na podstawie wiedzy o wielkości domu, a także jego umeblowaniu i w polączeniu $z$ innymi danymi można określić średni dochód rodziny, styl życia i codzienne zwyczaje.

Nieoczywiste i zaskakujące wykorzystanie informacji znaleźli naukowcy Uniwersytetu Stanforda: Michał Kosiński wspólnie z Yilun Wang ${ }^{38}$. Stworzony przez nich algorytm, na podstawie zdjęć zamieszczonych na popularnym portalu randkowym, pozwala $z$ dużym prawdopodobieństwem określić orientację seksualną osoby. W 81\% algorytm poprawnie wskazuje orientację seksualną mężczyzn, a w 74\% kobiet. Oprócz pytań o biologiczne podstawy orientacji seksualnej nasuwa się także pytanie o etykę stosowania takiego narzędzia.

\section{Podsumowanie}

Jednym z najważniejszych osiągnięć, jakie udało się uzyskać w wyniku reformy, jest objęcie przedsiębiorstw zagranicznych, z których usług korzystamy, europejskimi standardami, a także wzmocnienie konkretnych uprawnień, jak prawo do informacji, prawo

${ }_{37}$ M. Astor, Your Roomba May Be Mapping Your Home, Collecting Data That Could Be Shared, ${ }_{n}$ The New York Times", 25 VII 2017, https://www.nytimes.com/2017/07/25/technology/roomba-irobotdata-privacy.html?mcubz=1, 20 X 2017.

${ }_{38}$ S. Levi n, New AI can guess whether you're gay or straight from a photograph, "The Guardian”, 8 IX 2017, https://www.theguardian.com/technology/2017/sep/07/new-artificial-intelligence-can-tellwhether-youre-gay-or-straight-from-a-photograph, $20 \mathrm{X} 2017$. 
sprzeciwu (np. wobec profilowania) czy przeniesienia własnych danych ${ }^{39} . \mathrm{W}$ praktyce firmy amerykańskie, jak Facebook, Yahoo czy Google, będą musiały przestrzegać tych samych regul, co ich europejscy konkurenci. Pochodzenie usługi nie będzie juz miało znaczenia. Jeśli jest ona skierowana do Europejczyków, musi też gwarantować poszanowanie ich praw. RODO jest dla Amerykanów jasnym przekazem, że chociaż Internet jest ich wynalazkiem, to regulowanie działań $w$ Internecie jest również sprawą europejską. W ten sposób UE zapewniła swoim obywatelom większe prawa do ochrony danych osobowych, jednocześnie zwiększając odpowiedzialność przedsiębiorców. Korzyści wynikające z tych praw dla osoby fizycznej są dość oczywiste, a służą poprawie bezpieczeństwa oraz wspieraniu wolnego przepływu usług. Dostosowanie procesów biznesowych i polityk zarządzania danymi miało zakończyć się w maju 2018 r. Skuteczność RODO zależy od wielu zmian, m.in. redefinicji procesów biznesowych i polityk zarządzania danymi, identyfikacji źródeł przetwarzania danych $\mathrm{i}$ inwentaryzacji przepływów danych. W rozporządzeniu nie ma ściśle określonych wymagań wprowadzania zmian. Dlatego najbardziej pilną potrzebą jest doprecyzowanie regul postępowania oraz zdefiniowanie procedur.

Prawo do bycia zapomnianym stanowi ważny krok w kierunku wzmocnienia prawa do prywatności i ochrony danych osobowych obywateli UE. Jednak należy mieć na uwadze, że przepisy, jak wykazano w artykule, nie muszą być w każdym przypadku skuteczne i nie do każdej sytuacji mają zastosowanie. Dlatego oprócz jasnych reguł postępowania i przejrzystych procedur konieczne jest zachowanie "zdrowego rozsądku”. Przede wszystkim nie można dopuścić do sytuacji, kiedy staniemy się zakładnikami błędów przeszłości. UE dała nam do tego skuteczne, ale niedoskonałe narzędzie. W praktyce raz zamieszczoną w sieci informację jest niezwykle trudno usunąć. Dlatego fakt, ${ }_{n}$ że Internet nie zapomina, jest niemal egzystencjalnym zagrożeniem dla naszej możliwości zaczynania od nowa, przezwyciężania błędów przeszłości. [...] Cybersfera rzadko czyści nasze konta, a jej nadzorcy są surowsi od Wszechmocnego"40. Skoro nowoczesne społeczeństwa rejestrują każdą informację, to także wybaczanie blędów jest utrudnione albo nawet niemożliwe ${ }^{41}$.

39 Wypowiedź Katarzyny Szymielewicz dla: S. Wika riak, Google, Facebook czy Apple będq musiaty przestrzegać regut. Reforma ochrony danych osobowych stata sie faktem, , Gazeta Prawna”, 14 IV 2016, $\mathrm{http} / / /$ prawo.gazetaprawna.pl/artykuly/936232, reforma-ochrony-danych-osobowych.html, $16 \mathrm{X}$ 2017.

40 J. Rosen, Siec. Bez przebaczenia, „Gazeta Wyborcza”, 9 VIII 2010, http://wyborcza. $\mathrm{pl} / 1,76842,8224350$, Siec_Bez_przebaczenia.html, 10 I 2017.

41 V.Mayer-Schönberger, op. cit., passim. 


\section{Bibliografia}

\section{Dokumenty}

Rozporzadzenie Parlamentu Europejskiego i Rady (UE) 2016/679 z dnia 27 kwietnia 2016 r. w sprawie ochrony osób fizycznych w zwiqzku z przetwarzaniem danych osobowych $i$ w sprawie swobodnego przeplywu takich danych oraz uchylenia dyrektywy 95/46/WE (ogólne rozporzadzenie o ochronie dany(h), " Dziennik Urzędowy Unii Europejskiej” 2016, nr L 119, https://eur-lex.europa.eu/legal-content/PL/TXT/?qid=1539941625494\&uri=CELEX: 32016R0679, 11 X 2017.

Judgment of the Court (Grand Chamber), 13 May 2014, Google Spain SL and Google Inc. v Agencia Española de Protección de Datos (AEPD) and Mario Costeja González, http://eur-lex. europa.eu/legal-content/EN/ALL/?uri=CELEX:62012CJ0131, 10 X 2017.

\section{Raporty i ekspertyzy}

Attitudes on Data Protection and Electronic Identity in the European Union, June 2011, European Commission, http://ec.europa.eu/commfrontoffice/publicopinion/index.cfm/Survey/ getSurveyDetail/yearFrom/1974/yearTo/2011/surveyKy/864, 19 X 2018.

Google Transparency Report: Search removals under European privacy law, https:// transparencyreport.google.com/eu-privacy/overview, 17 X 2017.

\section{Monografie}

Barwik M., Księga wychodzenia za dnia. Tajemnice egipskiej Księgi Umartych, Warszawa 2009. Czubik A. [et al.], Nowe wyzwania dla ochrony praw czlowieka, Kraków 2017.

Mayer-Schönberger V., Delete: the Virtue of Forgetting in the Digital Age, Princeton-Oxford 2009.

Mayer-Schönberger V., Cukier K., Big Data. Rewolucja, która zmieni nasze myslenie, praç $i \dot{z} y c i e$, Warszawa 2014.

\section{Artykuły w czasopismach naukowych}

Halawa M., Nowe media i archiwizacja życia codziennego, „Kultura Współczesna” 2011, nr 11. Hilbert M., López P., How to Measure the World's Technological Capacity to Communicate, Store, and Compute Information Part I: Results and Scope, nnternational Journal of Communication" 2012, nr 6.

Krzysztofek M., ${ }_{n}$ Prawo do bycia zapomnianym ${ }^{n} i$ inne aspekty prywatnosici w epoce Internetu w prawie UEI, ${ }_{n}$ Europejski Przegląd Sądowy" 2012, nr 8.

\section{Źródła internetowe}

75 proc. Europejczyków chcialoby zapomnienia w sieci, Fundacja Panoptykon, 21 VI 2011, https://panoptykon.org/wiadomosc/75-proc-europejczykow-chcialoby-zapomnieniaw-sieci, 21 I 2018.

Astor M., Your Roomba May Be Mapping Your Home, Collecting Data That Could Be Shared, "The New York Times", 25 VII 2017, https://www.nytimes.com/2017/07/25/technology/ roomba-irobot-data-privacy.html?mcubz=1, 20 X 2017.

Bond S. E., Erasing the Face of History, "The New York Times", 14 V 2011, http://www. nytimes.com/2011/05/15/opinion/15bond.html?_r=1, 10 X 2017. 
Chwastowski K., Roxporzqdzenie PE $i$ Rady w sprawie ochrony osób fizycznych w zwiq̨ku z przetwarzaniem danych osobowych, ${ }_{n}$ Rzeczpospolita", 2 VI 2017, http://www.rp.pV Dane-osobowe/306029979-Rozporzadzenie-PE-i-Rady-w-sprawie-ochrony-osobfizycznych-w-zwiazku-z-przetwarzaniem-danych-osobowych.html, 16 X 2017.

Dauer U., Fleisher L., Former Formula One Chief Max Mosley Settles Legal Dispute With Google, ${ }_{n}$ The Wall Street Journal", 15 V 2015, https://www.wsj.com/articles/former-formulaone-chief-max-mosley-settles-legal-dispute-with-google-1431702038, 20 X 2017.

Górecki P., Wróżba z komputera, ${ }_{\text {Newsweek }}, 4$ XII 2010, www.newsweek.pV/nauka/wrozbaz-komputera,68916,1,1.html, 21 IX 2016.

Hendel J., In Europe, a Right to Be Forgotten Trumps the Memory of the Internet, "The Atlantic”, 3 II 2011, https://www.theatlantic.com/technology/archive/2011/02/in-europe-a-rightto-be-forgotten-trumps-the-memory-of-the-internet/70643/, 16 X 2017.

Ito A., Six Things Technology Has Made Insanely Cheap. Behold the power of American progress, ${ }_{n}$ Bloomberg", 5 II 2015, https://www.bloomberg.com/news/articles/2015-02-05/sixthings-technology-has-made-insanely-cheap?hootPostID=f0584f28d45d0ddc91cf8868 351d2ba6, 11 X 2017.

Kowalczuk-Pakuta: Skoñczyły się żarty z ochronq danych osobowych w UE ${ }_{n}$ Gazeta Prawna ${ }^{n}, 9$ VI 2016, http://prawo.gazetaprawna.pV/artykuly/950521,kowalczuk-pakula-skonczyly-siezarty-z-ochrona-danych-osobowych-w-ue.html, 15 X 2017.

Levin S., New AI can guess whether you're gay or straight from a photograph, "The Guardian”, 8 IX 2017, https://www.theguardian.com/technology/2017/sep/07/new-artificialintelligence-can-tell-whether-youre-gay-or-straight-from-a-photograph, $20 \mathrm{X} 2017$.

RODO - nowe przepisy o ochronie danych osobowych. Po co powstaty i dlaczego firmy muszq sig

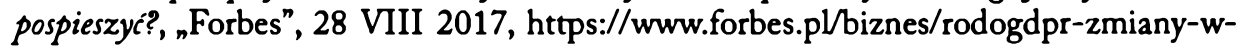
przepisach-o-ochronie-danych-osobowych/e9wq383, 20 X 2017.

Rosen J., Siec. Bez przebaczenia, "Gazeta Wyborcza", 9 VIII 2010, http://wyborcza. pl/1,76842,8224350,Siec_Bez_przebaczenia.html, 10 I 2017.

Rosen J., The Right to Be Forgotten, "The Atlantic", lipiec/sierpien 2012, https://www. theatlantic.com/magazine/archive/2012/07/the-right-to-be-forgotten/309044/,16 X 2017.

Sharwood S., Facebook Warehousing 180 PETABYTES of Data a Year, " The Register", 9 XI 2012, www.theregister.co.uk/2012/11/09/facebook_open_sources_corona/, 15 IX 2016.

Spence A., Prawo do bycia zapomnianym nowq formq cenzury? Krytyczny artykut dzienni-

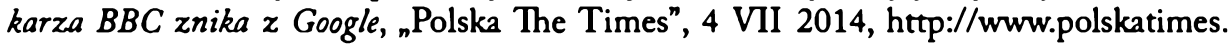
$\mathrm{pl}$ artykul/3495433, prawo-do-bycia-zapomnianym-nowa-forma-cenzury-krytycznyartykul-dziennikarza-bbc-znika-z-google,id,t.html, 20 X 2017.

Sullivan D., How Google's New ${ }_{n}$ Right To Be Forgotten Form Works: An Explainer, ${ }_{n}$ Search Engine Land", $30 \mathrm{~V}$ 2014, https://searchengineland.com/google-right-to-be-forgottenform-192837, 16 X 2017.

Szymaniak M., Polak odkryt politycznq bombe atomowq. To koniec demokracji jakq znamy?, TVN24, www.tvn24.pl/magazyn-tvn24/polak-odkryl-polityczna-bombe-atomowa-tokoniec-demokracji-jaka-znamy,79,1628, 24 I 2017.

Vincent J., Google Begins Implementation Of 'Right To Be Forgotten' Ruling With Online Takedown Form, "The Independent", $30 \mathrm{~V}$ 2014, http://www.independent.co.uk/life-style/ gadgets-and-tech/google-begins-implementation-of-right-to-be-forgotten-rulingwith-online-takedown-form-9459209.html, 16 X 2017. 
Wikariak S., Google, Facebook czy Apple będq musiaty przestrzegac regut. Reforma ocbrony danych osobowych stata sie faktem, "Gazeta Prawna", 14 IV 2016, http://prawo.gazetaprawna.pl/ artykuly/936232,reforma-ochrony-danych-osobowych.html, 16 X 2017.

Wikariak S., Prawo do bycia zapomnianym nie będzie w 100 proc. egzekwowalne, ${ }_{n}$ Gazeta Prawna", 25 IV 2016, http://prawo.gazetaprawna.pl/artykuly/938617,bielak-jomaa-prawodo-bycia-zapomnianym.html, 24 X 2017. 